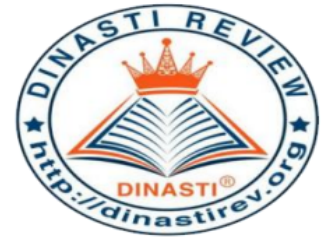

\title{
ANALISIS FAKTOR-FAKTOR YANG BERPENGARUH PADA PRODUKTIVITAS KERJA KARYAWAN
}

\author{
Tommi Setyo Pramono
}

Universitas Terbuka, Yogyakarta, Indonesia

\begin{tabular}{|c|c|}
\hline $\begin{array}{l}\text { ARTICLE INFORMATION } \\
\text { Received: } 7 \text { Mei } 2020 \\
\text { Revised: } 17 \text { Juni } 2020 \\
\text { Issued: } 2 \text { Agustus } 2020 \\
\text { Corresponding Author: First author } \\
\text { E-mail: tommisp@ gmail.com }\end{array}$ & $\begin{array}{l}\text { Abstrak: Salah satu usaha dalam rangka pencapaian } \\
\text { target suatu perusahaan adalah mempelajari kondisi dan } \\
\text { produktivitas kerja dari karyawan. Dengan pengukuran } \\
\text { produktivitas kerja dapat diukur sejauh mana } \\
\text { kemampuan karyawan dalam mencapai target yang } \\
\text { telah ditetapkan. Produktivitas kerja karyawan di } \\
\text { sebuah perusahaan termasuk di dalamnya adalah bank, } \\
\text { dapat dipengaruhi oleh beberapa faktor diantaranya } \\
\text { adalah kepemimpinan, lingkungan kerja dan jam kerja. } \\
\text { Penelitian ini bertujuan untuk mengetahui: (1) Pengaruh } \\
\text { kepemimpinan terhadap produktivitas kerja karyawan, } \\
\text { (2) Pengaruh kepuasan kerja terhadap produktivitas } \\
\text { kerja karyawan, (3) Pengaruh jam kerja terhadap } \\
\text { produktivitas kerja karyawan, dan (4) Pengaruh } \\
\text { kepemimpinan, kepuasan kerja dan jam kerja terhadap } \\
\text { produktivitas kerja karyawan. Bersumber dari } \\
\text { penelitian-penelitian terdahulu, muncul perumusan } \\
\text { masalah selanjutnya untuk mengetahui pengaruh } \\
\text { kepemimpinan, lingkungan kerja dan jam kerja terhadap } \\
\text { produktivitas kerja pada instansi lainnnya terutama di } \\
\text { sektor perbankan. Dengan demikian akan dapat } \\
\text { ditemukan apakah ada keterkaitan masing-masing } \\
\text { variabel terhadap produktivitas kerja dan apakah ada } \\
\text { pengaruh dari ketiga variabel terhadap produktivitas } \\
\text { karyawan yang dapat diteliti pada berbagai instansi. } \\
\text { Kata Kunci: Kepemimpinan, lingkungan, waktu kerja, } \\
\text { produktivitas }\end{array}$ \\
\hline
\end{tabular}

\section{PENDAHULUAN}

Sumber daya manusia dalam sebuah perusahaan merupakan salah satu faktor yang berperan sangat penting. Hal tersebut terkait dengan adanya korelasi yang kuat antara kualitas perusahaan dengan kualitas sumber daya manusia yang berfungsi sebagai karyawan dan juga pelaku layanan dalam perusahaan tersebut. Pada dasarnya sebuah perusahaan atau instansi tidak hanya mengharapkan memiliki karyawan yang memiliki kemampuan tinggi, cakap, terampil dan giat bekerja, namun diharapkan juga berkeinginan untuk mencapai produktivitas 
kerja yang tinggi (Yuli, 2005). Tingkat produktivitas kerja karyawan dalam berbagai perusahaan ataupun instansi hingga saat ini masih dianggap sebagai masalah yang sangat perlu dikaji. Hal itu dikarenakan dengan adanya pengkajian tingkat produktivitas kerja karyawan, dapat diketahui bagaimana perlakuan dan pemanfaatan sumber daya yang ada untuk mencapai prinsip efektivitas dan efisiensi. Sesuatu yang dapat dikatakan efisien apabila dilakukan dengan memperhatikan aspek biaya, sarana prasarana, sumber daya (manusia dan material), serta waktu seminimal mungkin, sedangkan dikatakan efektif apabila pemanfaatan berbagai aspek tersebut benar-benar tepat sasaran dan tujuan yang diinginkan (Kamuli, 2012).

Beberapa faktor yang mempengaruhi tingkat produktivitas kerja antara lain kepemimpinan, lingkungan kerja dan jam kerja yang dibutuhkan untuk mencapai produktivitas kerja untuk mencapai tujuan perusahaan. Pada umumnya, seorang pekerja akan bekerja dalam melaksanakan tugas dan tanggung jawabnya sangat dipengaruhi oleh gaya kepemimpinan dari atasannya baik dari manajer, pimpinan perusahaan atau instansi (Saleh\&Utomo, 2010).

Penelitian Anggun (2015) yang melakukan studi pada Bank BJB menunjukkan bahwa kepemimpinan dan kepuasan kerja mempunyai pengaruh besar terhadap motivasi kerja dari karyawan Bank BJB Cabang Ciamis. Penelitian tersebut dilakukan dengan menggunakan metode penelitian deskriptif kuantitatif untuk meneliti pengaruh variabel bebas terhadap variabel terikat. Selain kepemimpinan, Man\&Ling (2014) juga melakukan penelitian tentang pengaruh jam kerja dan produktivitas dengan studi kasus "Food Services and Information Communication Industries" di Hongkong. Hasil penelitian menyatakan bahwa durasi jam kerja dan produktivitas secara statistik tidak signifikan antara dua industri tersebut. Hal ini dapat diartikan bahwa pengaruh atau tidaknya suatu variabel terhadap variabel lainnya juga berkaitan dengan karakteristik perusahaan dan variabel-variabel lainnya. Tuti (2014) dalam penelitiannya menyimpulkan bahwa kerja lembur dapat menurunkan produktivitas tenaga kerja Konstruksi sebesar 8.87\%-11.84\% dan meningkatkan ketidakhadiran pekerja karena sakit. Hal ini didukung oleh penelitian Shahid dkk (2018) bahwa jam kerja berlebih menyebabkan stress kerja dan mempengaruhi performa dan produktivitas di sektor Bank.

Dari beberapa penelitian sebelumnya tersebut, ditemukan banyak variabel yang menentukan tingkat produktivitas kerja pada para karyawan. Untuk itu, timbul pemikiran untuk membahas lebih lanjut pengaruh kepemimpinan, lingkungan kerja dan jam kerja terhadap produktivitas kerja karyawan yang dilakukan pada instansi lainnya terutama sektor perbankan. Dengan demikian akan dapat ditemukan apakah ada keterkaitan masing-masing variabel terhadap produktivitas kerja dan apakah ada pengaruh dari ketiga variabel terhadap produktivitas karyawan.

\section{KAJIAN PUSTAKA}

\section{Produktivitas Kerja}

Produktivitas kerja karyawan bagi suatu perusahaan sangatlah penting sebagai alat ukur tingkat keberhasilan dalam menjalankan usaha. Dengan semakin tingginya produktivitas kerja karyawan dalam perusahaan, dapat diartikan laba perusahaan dan tingkat produktivitas akan meningkat. Hasibuan (2005) menyebutkan bahwa produktivitas adalah perbandingan secara ilmu hitung antara jumlah yang dihasilkan dan jumlah setiap sumber yang dipergunakan selama produksi berlangsung. Sumber tersebut dapat berupa tanah, bahan baku dan bahan pembantu, pabrik, mesin-mesin dan alat-alat serta tenaga kerja. 
Menurut Kusnendi (2003), konsep produktivitas pada dasarnya dapat dilihat dari dua dimensi, yaitu dimensi individu dan dimensi perusahaan. Pengkajian masalah produktivitas dari dimensi individu tidak lain melihat produktivitas terutama dalam hubungannya dengan karakteristik-karakteristik kepribadian individu. Produktivitas sendiri dapat diartikan sebagai sikap mental yang selalu mempunyai pandangan bahwa mutu kehidupan hari ini harus lebih baik dari hari kemarin, dan hari esok harus lebih baik dari hari ini.

Dalam upaya meningkatkan produktivitas kerja karyawan di suatu perusahaan perlu memperhatikan faktor-faktor yang mempengaruhi produktivitas kerja karyawan tersebut. Banyak faktor yang dapat mempengaruhi produktivitas kerja karyawan baik yang berhubungan dengan tenaga kerja itu sendiri maupun faktor-faktor yang berhubungan dengan lingkungan perusahaan dan kebijakan pemerintah secara keseluruhan.

Menurut Pandji (2005). Ada 10 faktor yang sangat diinginkan oleh para karyawan untuk meningkatkan produktivitas kerja karyawan, yaitu: (1) pekerjaan yang menarik, (2) upah yang baik, (3) keamanan dan perlindungan dalam pekerjaan, (4) etos kerja dan (5) lingkungan atau sarana kerja yang baik, (6) promosi dan perkembangan diri mereka sejalan dengan perkembangan perusahaan, (7) merasa terlibat dalam kegiatan-kegiatan perusahaan, (8) pengertian dan simpati atas persoalan-persoalan pribadi, (9) kesetiaan pimpinan pada diri sipekerja, (10) Disiplin kerja yang keras.

Menurut Simanjutak (1985) faktor yang mempengaruhi produktivitas kerja karyawan perusahaan dapat digolongkan pada dua kelompok, yaitu:

1) Yang menyangkut kualitas dan kemampuan fisik karyawan yang meliputi: tingkat pendidikan, latihan, motivasi kerja, etos kerja, mental dan kemampuan fisik karyawan

2) Sarana pendukung, meliputi:

a. Lingkungan kerja, meliputi: produksi, sarana dan peralatan produksi, tingkat keselamatan, dan kesejahteraan kerja.

b. Kesejahteraan karyawan, meliputi: Manajemen dan hubungan industri.

Menurut Sinaga (2016), lingkungan kerja merupakan salah satu faktor penting dalam meningkatkan produktivitas karyawan. Lingkungan kerja mempunyai pengaruh langsung terhadap karyawan didalam menyelesaikan pekerjaan yang pada akhirnya akan meningkatkan produktivitas perusahaan. Suatu kondisi lingkungan kerja dikatakan baik apabila karyawan dapat melaksanakan kegiatan secara optimal, sehat, aman, dan nyaman. Terdapat dua jenis lingkungan kerja yaitu lingkungan kerja fisik dan lingkungan kerja non fisik. Lingkungan kerja fisik merupakan lingkungan atau kondisi tempat kerja yang dapat mempengaruhi atau meningkatkan efesiensi kerja dan lingkungan kerja non fisik adalah semua keadaan yang terjadi yang berkaitan dengan hubungan kerja, baik hubungan dengan atasan maupun hubungan dengan bawahan sesama rekan kerja, ataupun hubungan dengan bawahan (Sarwoto, 2007).

\section{Pengukuran Produktivitas Kerja}

Untuk mengetahui produktivitas kerja dari setiap karyawan maka perlu dilakukan sebuah pengukuran produktivitas kerja. Menurut Simamora (2014) faktor-faktor yang digunakan dalam pengukuran produktivitas kerja meliputi kuantitas kerja, kualitas kerja dan ketepatan waktu.

Mengukur produktivitas kerja menurut dimensi perusahaan menurut Alan Thomas (Kusnendi, 2003) yang secara matematis hubungannya diformulasikan sebagai berikut: 


$$
O_{i}=g\left(I_{1}, I_{2}, \ldots \ldots, I_{n}\right)
$$

Dimana $O_{i}$ adalah output, sedangkan adalah sejumlah input yang dipergunakan dalam mencapai output tertentu. Dengan kata lain formula diatas dapat diperjelas kepada formula yang lebih dipahami, yakni sebagai berikut:

$$
P=\frac{O}{I}
$$

Keterangan:

$\mathrm{P}$ : Produktivitas

O : Output

I : Input

Pengukuran produktivitas kerja ini mempunyai peranan penting untuk mengetahui produktivitas kerja dari para karyawan sehingga dapat diketahui sejauh mana produktivitas yang dapat dicapai oleh karyawan. Selain itu pengukuran produktivitas juga dapat digunakan sebagai pedoman bagi para manajer untuk meningkatkan produktivitas kerja sesuai dengan apa yang diharapkan oleh perusahaan.

\section{Kepemimpinan}

Yuli (2005) menjelaskan bahwa Davis mendefinisikan kepemimpinan sebagai kemampuan untuk membujuk orang lain dalam mencapai tujuan yang telah ditetapkan secara antusias. Dengan demikian, kepemimpinan merupakan kecakapan atau kemampuan seseorang untuk membujuk orang lain agar bersedia bekerja keras dalam mencapai tujuan organisasi yang telah ditetapkan.

Menurut Suddin\&Sudarman (2010), Terry dan Frankin mendefinisikan kepemimpinan adalah hubungan di mana seorang pemimpin mampu mempengaruhi orang lain untuk mau bekerja sama melaksanakan tugas-tugas dengan saling berkaitan untuk mencapai tujuan yang diinginkan pemimpin dan atau kelompok. Definisi tersebut menekankan pada permasalahan hubungan antara orang yang mempengaruhi (pemimpin) dengan orang yang dipengaruhi (bawahan). Pimpinan adalah seseorang yang memiliki kewenangan untuk memberi tugas, memiliki kemampuan untuk membujuk atau mempengaruhi orang lain dan juga memiliki otoritas manajerial terhadap (bawahan). Menurut Hery (2018), Robert House telah mengidentifikasi berbagai perilaku kepemimpinan sebagai berikut: (a) pemimpin yang mengarahkan (directive leader); (b) pemimpin yang mendukung (supportive leader); (c) pemimpin yang partisipatif (participative leader); dan (d) pemimpin yang berorientasi pada prestasi (achievement oriented leader).

\section{Kepuasan Kerja}

Dalam setiap perusahaan selalu berlaku prinsip bahwa karyawan yang memiliki komitmen kinerja yang tinggi akan menghasilkan kinerja yang lebih baik sehingga arah pencapaian tujuan dari organisasi atau perusahaan dapat tercapai. Untuk itu perlu dilakukan survei sikap untuk mendapatkan respon dari karyawan mengenai perasaan mereka terhadap pekerjaan, tim kerja, penyelia dan organisasi. Apabila tampak persepsi yang menyimpang akan dapat menimbulkan sikap negatif tentang pekerjaan dan organisasi yang harus diketahui oleh manajemen. 
Penggunaan survei sikap secara teratur dapat menyiagakan manajemen terhadap masalahmasalah potensial dan niat para karyawan sehingga tindakan bisa diambil untuk mencegah berbagai akibat negatif (Robbins, 2015).

Dalam teori Maslow dikatakan bahwa setelah suatu kebutuhan seseorang dalam hierarki kebutuhan secara substansial terpenuhi, maka yang bersangkutan tidak akan termotivasi lagi pada kebutuhan tersebut. Jika mengacu pada teori tersebut, maka pimpinan organisasi perlu memahami pada tingkat kebutuhan mana karyawan tersebut berada, kemudian fokuslah untuk memenuhi kebutuhan tersebut atau kebutuhan yang ada diatasnya sehingga karyawan akan merasa puas. Sementara menurut McClelland terdapat teori 3 kebutuhan yang juga terkait dengan munculnya motivasi, yaitu: kebutuhan akan prestasi, kekuasaan dan afiliasi. Dengan adanya kebutuhan akan prestasi yang tinggi akan menyebabkan karyawan berjuang untuk pencapaian prestasi pribadi, mengejar jabatan dan penghargaan. Dari hal itulah akan muncul motivasi yang tinggi dari karyawan untuk bekerja lebih keras. Untuk itu peran dari manajer atau pimpinan organisasi adalah meningkatkan motivasi kerja dari karyawan atau anak buahnya sehingga tujuan organisasi dapat tercapai.

Salah satu upaya untuk mencapai kepuasan karyawan sehingga menimbulkan motivasi untuk mencapai kinerja maksimal adalah dengan melakukan upaya penetapan tujuan yang partisipatif (melibatkan karyawan) sehingga menghasilkan kinerja yang lebih baik. Selain itu, perlu pula adanya umpan balik sehingga karyawan dapat memperbaiki kinerjanya terhadap upaya pencapaian tujuan. Umpan balik tersebut akan membantu mengidentifikasi kesenjangan antara apa yang telah dilakukan dan apa yang seharusnya mereka lakukan. Untuk memaksimalkan motivasi karyawan, para manajer harus memiliki fleksibilitas sebagai bentuk respon organisasi atau perusahaan terhadap kebutuhan dasar pada karyawannya. Hal itu telah diimplementasikan pada sejumlah organisasi dan berhasil meningkatkan kepuasan kerja karyawan.

\section{Waktu Kerja}

Gumanti (2015) menjelaskan bahwa dikatakan sebagai waktu kerja lembur adalah waktu kerja yang melampaui 8 jam per hari dan 40 jam per minggu. Dari penelitian-penelitinan yang sudah dilakukan mengenai pengaruh kerja lembur terhadap produktivitas tenaga kerja, terlihat adanya penurunan produktivitas, yang berakibat pada peningkatan biaya tenaga kerja. Namun demikian, seberapa besar produktivitas berkurang, dan seberapa besar peningkatan biaya terjadi, belum cukup banyak dilakukan penelitian secara mendalam. Ada beberapa hal yang menyebabkan terjadinya penurunan produktivitas pada jam lembur adalah:
a. menurunnya kecepatan kerja;
b. mangkirnya pekerja akibat kelelahan;
c. meningkatnya kecelakaan kerja;
d. kelelahan yang berlebihan pada pekerja;
e. menurunnya semangat pekerja;
f. tingginya arus pekerja yang masuk dan berhenti bekerja;
g. masalah supervisi. 


\section{METODE PENELITIAN}

Penelitian ini menggunakan metode penelitian deskriptif-kualitatif dengan melakukan kajian teori secara deskriptif untuk digunakan mengumpulkan, merangkum serta menginterpretasikan data-data yang diperoleh dari penelitian-penelitian sebelumnya, jurnal dan telaah pustaka. Hasil analisis telaah pustaka selanjutnya diolah kembali untuk menggambarkan kondisi/fakta di lapangan sehingga diharapkan dapat menghasilkan gambaran yang jelas, terarah dan menyeluruh dari masalah yang akan menjadi penelitian yang dilaksanakan berikutnya (Suharsaputra, 2012).

\section{HASIL DAN PEMBAHASAN}

\section{Pengaruh kepemimpinan terhadap produktivitas kerja}

Gaya kepemimpinan mempunyai peranan penting dalam sebuah perusahaan untuk mencapai tujuan dan meningkatkan kinerja. Dengan kepemimpinan yang baik akan memberikan kenyamanan dan motivasi bagi karyawan sehingga produktivitas kerja akan meningkat. Akan tetapi kriteria gaya kepemimpinan berbeda-beda antar karyawan sehingga perlu adanya penelitian apakah kepemimpinan berpengaruh secara signifikan terhadap produktivitas kerja karyawan.

\section{Pengaruh kepuasan kerja terhadap produktivitas kerja}

Suatu organisasi sebaiknya menyediakan tempat yang representatif untuk melaksanakan pekerjaan atau tugas bagi karyawan. Karyawan tidak mungkin dapat bekerja dengan tenang dan maksimal jika tempat yang tersedia tidak dapat memberikan kenyamanan. Semangat kerja karyawan sangat dipengaruhi oleh keadaan lingkungan kerja non fisik, misalnya hubungan dengan sesama karyawan dan dengan pemimpinnya. Dalam penelitiannya Sudin \& Sudarman (2010) menyatakan bahwa faktor lingkungan kerja, kepemimpinan dan motivasi sangat mempengaruhi kinerja dan produktivitas karyawan. Faktor-faktor tersebut sangat mempengaruhi produktivitas kerja karyawan. Semakin baik dan nyaman suatu lingkungan kerja, akan meningkatkan motivasi kerja karyawan dan luarannya adalah meningkatnya produktivitas kerja karyawan pada sebuah karyawan.

Terdapat pula teori Frederick Herzberg yang disebut juga sebagai teori higienes yang menyatakan bahwa terdapat 2 faktor yang akan menjadi teori awal tentang motivasi. Hal itu adalah teori intrinsik yang terkait dengan kepuasan kerja dan teori ekstrinsik yang berhubungan dengan ketidakpuasan kerja. Herzberg menyimpulkan bahwa seseorang yang merasa sangat puas (nyaman) dengan pekerjaan mereka dipengaruhi oleh faktor intrinsik yang merupakan motivator, sedangkan faktor ekstrinsik yang menyebabkan ketidakpuasan bekerja disebut sebgaai faktor higienis. Ketika seseorang merasa nyaman dengan pekerjaan mereka, maka mereka akan cenderung menyebutkan faktor-faktor intrinsik yang timbul dari pekerjaan mereka misalnya pencapaian, prestasi, kemajuan, perkembangan dan pengakuan. Hal-hal tersebut merupakan bentuk-bentuk kebutuhan untuk dihargai dan kebutuhan aktualisasi diri yang mana keduanya merupakan hierarki tertinggi dari kebutuhan dasar manusia. Di lain pihak, ketika mereka tidak merasa puas, maka mereka akan menyebutkan faktor-faktor ekstrinsik yang timbul dari konteks pekerjaan mereka seperti adanya pengawasan, kebijakan perusahaan, 
kondisi kerja, gaji, hubungan rekan kerja, hubungan dengan atasan ataupun bawahan dan lain sebagainya.

\section{Pengaruh jam kerja terhadap produktivitas kerja}

Gumanti (2015) menyatakan adanya hubungan yang berarti antara jam kerja dengan produktivitas kerja. Jam kerja lembur akan berdampak negatif yaitu kelelahan yang berlebihan pada pekerja, menurunnya produktivitas dan keselamatan kerja, dan meningkatnya ketidakhadiran pekerja karena sakit (Sumarningsih, 2014).

\section{Pengaruh kepemimpinan, kepuasan kerja dan jam kerja terhadap produktivitas kerja}

Telah diuraikan bahwa secara sendiri-sendiri variabel kepemimpinan, lingkungan kerja dan jam kerja diduga memiliki pengaruh yang kuat terhadap produktivitas kerja. Dengan demikian jika variabel ini dihubungkan secara bersama-sama terhadap produktivitas kerja maka akan diperoleh dampak yang lebih tinggi. Dimana jika kepemimpinan, lingkungan kerja dan jam kerja baik maka akan meningkatkan produktivitas yang lebih baik pula. Berdasarkan kerangka berpikir, skema dalam penelitian ini adalah sebagai berikut:

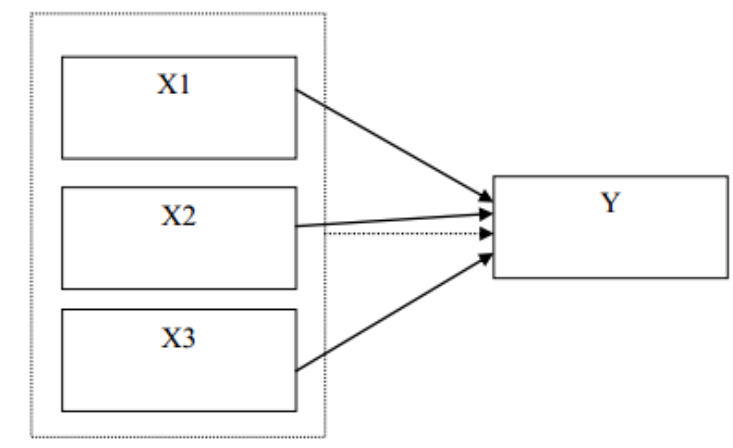

Gambar 1. Paradigma Penelitian

Keterangan:

$\mathrm{X} 1$ : Kepemimpinan

$\mathrm{X} 2$ : Kepuasan Kerja

X3 : Jam Kerja

Y : Produktivitas Kerja

$\rightarrow \quad$ : Pengaruh masing-masing variabel $\mathrm{X}$ terhadap $\mathrm{Y}$

$\rightarrow$ : Pengaruh ketiga variabel X secara bersama-sama terhadap Y

Lingkungan kerja yang nyaman dan kondusif akan meningkatkan motivasi karyawan untuk bekerja dan hal ini berkaitan dengan peningkatan produktivitas kerja. Lingkungan yang nyaman juga akan meminimalisir resiko stress bekerja karena beban pekerjaan karyawan. Selain itu, durasi jam kerja yang berlebihan dikaitkan dengan produktivitas yang lebih rendah, kinerja kerja yang buruk, masalah kesehatan dan motivasi karyawan yang rendah. Dengan demikian, kebijakan durasi jam kerja pada suatu perusahaan sangat berpengaruh pada hasil yang ingin dicapai oleh perusahaan.

Oleh karena itu, penentuan dan penciptaan lingkungan kerja yang baik akan sangat menentukan keberhasilan pencapaian tujuan perusahaan. Sebaliknya apabila lingkungan kerja 
yang tidak baik akan dapat menurunkan motivasi serta semangat kerja dan akhirnya dapat menurunkan produktivitas kerja karyawan. Lingkungan kerja sangatlah perlu untuk diperhatikan karena merupakan salah satu faktor yang penting dalam meningkatkan produktivitas kerja karyawan. Kedua jenis lingkungan kerja diatas harus selalu diperhatikan oleh perusahaan. Keduanya tidak bisa dipisahkan begitu saja, terkadang perusahaan hanya mengutamakan salah satu jenis lingkungan kerja diatas, tetapi akan lebih baik lagi apabila keduanya dilaksanakan secara maksimal. Dengan begitu kinerja karyawan bisa lebih maksimal.

Rahmawati (2016) meneliti pengaruh nilai kerja terhadap produktivitas kerja karyawan menggunakan metode deksriptif kuantitatif. Hasil analisis menunjukkan bahwa kontribusi nilai kerja terhadap produktivitas sebesar 48, 7\%. Dessyta (2015), Saleh \&Utomo (2018) dan Heny (2015) menyatakan bahwa tata ruang kantor atau lingkungan kerja berpengaruh terhadap produktivitas kerja pegawai badan pembedayaan masyarakat (BPM) Kabupaten Solok. Selain itu, displin kerja, kepemimpinan dan motivasi juga meningkatkan kinerja pegawai yang juga meningkatkan produktivitas kerja (Christian dkk, 2014). Dengan demikian, kondisi utama karyawan yang semakin penting dan menentukan tingkat produktivitas karyawan yaitu pendidikan dan pelatihan, motivasi, disiplin, ketrampilan, tingkat penghasilan, lingkungan dan jam kerja, dan kepemimpinan. Dengan harapan agar karyawan mempunyai semangat dalam bekerja dan akhirnya dapat meningkatkan mutu pekerjaan, meningkatkan produksi dan produktivitas kerja. Dalam penelitian Ariani, dkk (2020) menunjukkan bahwa disiplin kerja, iklim organisasi dan komitmen organisasi memiliki pengaruh positif yang signifikan terhadap produktivitas kerja guru di Sekolah Dasar Islam Assidiqiyah Ciledug.

Berdasarkan deskripsi teoritis, kerangka berfikir, dan hasil-hasil penelitian yang relevan diatas, dapat ditarik hipotesis penelitian yang merupakan jawaban sementara dari masalah penelitian yang telah dirumuskan, yaitu sebagai berikut:

1. Terdapat pengaruh positif kepemimpinan terhadap produktivitas kerja

2. Terdapat pengaruh positif kepuasa kerja terhadap produktivitas kerja

3. Terdapat pengaruh positif jam kerja terhadap produktivitas kerja

4. Terdapat pengaruh positif secara bersama sama antara kepemimpinan, lingkungan kerja dan jam kerja terhadap produktivitas kerja

\section{KESIMPULAN DAN SARAN}

Dari telaah pustaka ini disimpulkan bahwa terdapat pengaruh yang positif antara gaya kepemimpinan, kepuasan kerja dan jam kerja terhadap produktivitas kerja suatu instansi atau perusahaan. Untuk itu perlu dilakukan penelitian lebih lanjut dalam bentuk metode kuantitatif berupa pengamatan nyata menggunakan instrumen penelitian angket/kuesioner pada beberapa sektor perbankan.

\section{DAFTAR RUJUKAN}

Anggun, P.A. 2017. "Pengaruh Kepemimpinan Dan Kepuasan Kerja Terhadap Motivasi Kerja Karyawan: Studi Pada Bank BJB Cabang Ciamis". Journal of Management Review. Vol. 1(3), pp: 107-112. 
Ariani, D., Saputri, I.P., Suhendar, I.A. 2020. "Pengaruh Disiplin Kerja, Iklim Organisasi dan Komitmen Organisasi terhadap Produktivitas Kerja Guru”. Jurnal Ilmu Manajemen Terapan, 1(3), 268-279. https://doi.org/10.31933/jimt.v1i3.110

Christian, K., Silvya, L.M., dan Lisbeth, M. 2014. "Pengaruh Disiplin Kerja Kepemimpinan Dan Motivasi Terhadap Kinerja Pegawai Pada PT. PLN (Persero) Wilayah Suluttenggo Area Manado". Jurnal EMBA. Vol.2 (3), pp: 1592-1602.

Gumanti, D. 2015. "Hubungan Jam Kerja, Tata Ruang Kantor Dan Pengawasan Dengan Produktivitas Kerja Pegawai Badan Pemberdayaan Masyarakat (BPM) Kabupaten Solok”. Journal of Economic Education. Vol.4 (1), pp: 42-51.

Hasibuan, S.P.M. 2005. Manajemen Sumber Daya Manusia. Edisi Revisi. Jakarta: Bumi Aksara.

Heny, S. 2015. "Pengaruh Lingkungan Kerja, Disiplin Kerja Dan Motivasi Kerja Terhadap Kinerja Pegawai Negeri Sipil di Sekretariat DPRD Kabupaten Madiun”. Jurnal JIBEKA. Vol.9(1), pp: 44-53.

Hery. 2018. Pengantar Manajemen. Jakarta: Gramedia

Kamuli, S. 2012. "Pengaruh Iklim Perusahaan Terhadap Produktivitas Kerja Pegawai di Sekretariat Daerah Kota Gorontalo”. Jurnal Inovasi. Vol. 9, pp:1693-9034.

Pandji, A. 2005. Psikologi Kerja. Jakarta: Rineka Cipta

Rahmawati, H. 2016. Pengaruh Nilai Kerja Terhadap Produktivitas Kerja Karyawan Produksi. Tugas Akhir. Malang: Universitas Muhammadiyah Malang.

Kusnendi. 2003. Ekonomi Sumber Daya Manusia dan Alam. Jakarta:Universitas Terbuka.

Man, N.C, dan Ling, T.W. 2014. "Relationships between Working Hours and Productivity: The Case of Food Services and Information Communication Industries in Hong Kong". Advances in Economics and Business. Vol. 2(7), pp: 281-292.

Saleh, A.R., dan Utomo, H. 2010. "Pengaruh Disiplin Kerja, Motivasi Kerja, Etos Kerja Dan Lingkungan Kerja Terhadap Produktivitas Kerja Karyawan Bagian Produksi Di PT. INKO JAVA Semarang". Among Makarti. Vol. 11(21), pp: 28-50

Sarwoto. 2007. Dasar-dasar Organisasi Manajemen. Jakarta: Ghalia Indonesia

Shahid, M.N., Latif, K., Sohail, N., dan Ashraf, M.A. 2018. "Work Stress And Employee Performance In Banking Sector Evidence From District Faisalabad, Pakistan". Asian Journal of Business and Management Sciences. Vol. 1(7), pp: 38-47.

Sinaga, S. 2016. "Pengaruh Lingkungan Kerja terhadap Produktivitas Kerja Karyawan (Bagian Produksi Minyak Kelapa Sawit PT. Mitra Unggul Pusaka Segati Pelalawan Riau)”. JOM FISIP. Vol.3(2):1-13.

Simamora, H. 2014. Manajemen Sumber Daya Manusia. Edisi Ketiga. Yogyakarta: STIE YKPN

Simanjuntak, P.J. 1985. Pengantar Ekonomi Sumber Daya Manusia. Jakarta: Penerbit FE UI. Suddin, A., \& Sudarman. 2010. "Pengaruh Kepemimpinan, Motivasi, Dan Lingkungan Kerja Terhadap Kinerja Pegawai Kecamatan Laweyan Kota Surakarta”. Jurnal Manajemen Sumberdaya Manusia. Vol 4.(1), pp: 1-8.

Suharsaputra, U. 2012. Metode Penelitian: Kuantitatif, Kualitatif dan Tindakan. Bandung: Refika Aditama.

Sumarningsih, T. 2014. "Pengaruh Kerja Lembur pada Produktivitas Tenaga Kerja Konstruksi”. Jurnal Ilmu dan Terapan Bidang Teknik Sipil. Vol. 20 (1), pp: 63:69. 
Yuli, S.B.C. 2005. Manajemen Sumber Daya Manusia, Malang:UMM Press. 